\title{
Din nou despre postmodernism și actualitate - Dumitru Radu Popa, ,Din partea cealaltă (2008 - 2013)”
}

\author{
Prof. univ. dr. Simona ANTOFI \\ Centrul interdisciplinar de studii culturale central și sud-est europene, \\ Universitatea „Dunărea de Jos”, Galați
}

Résumé: La récupération, à l'aide de la mémoire affective, des bribes appartenant à l'espace roumain et également à celui américain propose un monde possible où les réalités culturelles et les modèles spirituels auxquels l'auteur se rapporte coexistent avec des bizarreries du monde d'au delà de l'océan, sans hiérarchie et sans marges plus ou moins symboliques.

Mots-clé: essai, marges culturelles, puzzle, modèles spirituels.

A doua parte a periplului intitulat Din partea cealaltă [1], semnat de Dumitru Radu Popa, se constituie din patru secvențe - Pe firul amintirii, Americane, Culturale, literare și De prin lume adunate, care continuă dialogul mentalitar și cultural dintre cele două lumi, privite una ca fiind partea cealaltă a celei de-a doua, și invers. Dialog marcat explicit de un lirism al amintirii nostalgice pentru care întoarcerea în timp reprezintă o cale de recuperare, prin terapeutica scrisului, a unei istorii personale cândva viciate de nerăbdarea timpului.

Ca demne restituiri ale unei lumi apuse, figuri tutelare luminoase precum cele ale lui Șerban Cioculescu, Vladimir Streinu, Bogdan Pitești - un Mecena al timpurilor moderne, Alexandru Piru, Cella Delavrancea, Edgar Papu, Romul Munteanu și Mircea Horia Simionescu jalonează un indirect traseu de formare intelectuală de o neprețuită - atunci ca și acum - contiguitate cu spirite de autentici cărturari.

Cursurile - de multe ori facultative - pe care acești oameni de litere le propuneau - Cafeneaua literară - Șerban Cioculescu: „înțelegea cafeneaua literară așa cum a fost între cele două războaie mondiale, drept o însemnată instituție de cultură și nu... locul de pierzanie, nefacere de nimic, cum apărea în propaganda oficială."[2], sunt pline de informații obligatorii pentru formarea viitorilor intelectuali. Se adaugă Estetica poeziei moderne - Vladimir Streinu: „După ce cursul de deschidere a avut amfiteatrul plin, nu a trebuit prea mult, slavă 
Domnului, să rămânem numai vreo 15 studenți, dar efectiv interesați de Hugo Friedrich și Abatele Brémond, de analize aplicate pe Lautréamont și Ion Barbu"[3], sau sensibilitățile ascunse cu grijă ale acestor profesori care se formaseră, la rându-le, majoritatea, ca asistenți ai divinului critic, G. Călinescu. Așa de pildă, Alexandru Piru își primește urătorii de Crăciun cu mare emoție „abia atunci l-am observant pe professor, sprijinit de marginea ferestrei dimpotrivă, îmbrăcat în costum de gală și cu cravată. Nemișcat, din ochi i se scurgeau lacrimi pe obraz, de care nu se sinchisea; lacrimi mari, foarte mari".[4] Și astfel, toți acești critici, istorici literari și dascăli devin oameni vii - cu toții, sub vremi - păstrându-și, însă, demnitatea pe care numai frecventarea marilor cărți ale literaturii, adică adevărata cultură, o poate da.

Iar Cella Delavrancea, fiica lui Barbu Ștefănescu și nepoata unui căruțaș, care copilărise, practic, în casa lui Caragiale, împreună cu Ecaterina și Luca Ion, și care este invitată să concerteze, pe când avea 12 ani, pentru împăratul Wilhelm al Prusiei, mult mai târziu, în perioada comunistă, îi învăța pe câțiva foști țărani deveniți brusc proletari cum să care mai cu spor varza, dând-o din mână în mână, totul pentru o „porție de mâncare la prânz, la birtul din colț, și ceva să poată duce acasă, la pisici". [5]

Germanist de formație, comparatistul Romul Munteanu propune și pune în practică, parțial, un proiect cultural de anvergură - „proiectul lui cultural, unul dintre cele mai îndrăznețe ale perioadei postbelice, era crearea unei biblioteci universale în limba română, reluând astfel un ideal atât de drag al lui Ioan Heliade Rădulescu. De la spațiul european el a extins interesul literar către teritoriul romanului american și sud-american, al prozei și poeziei africane, al literaturii orientale - China, Japonia și India". [6] Astfel de oameni supraviețuiesc cum pot într-o lume întoarsă pe dos, comunistă, necunoscătoare și nerecunoscătoare - în raport cu noblețea spiritului și cu umanitatea profundă din acești cărturari care aduc cu ei un inefabil aer de melancolie și de regret după un sistem de valori pierdut iremediabil.

Seria de secvențe americane propune un puzzle de eșantioane de realitate ai căror protagoniști sunt dolarul, torționarul cel ...bun, Deuce Matinez („,cel care, în numai șase luni de interogare, a putut construi un caz împotriva lui Khalid" [7] - terorist arab extrem de periculos), muzeele și accesul la cultură - Muzeul Guggenheim, opera de artă a unui arhitect vizionar: „Și, poate mai mult decât toate acestea, vor stârni interesul schițele, proiectele arhitecturale și machetele pentru fantasticul Centru Cultural din Bagdad, o obsesivă spirală care să cinstească memoria lui Haroun al Raschid"[8], sau o teologie a invalidității secondată de o convenție asupra drepturilor și demnităților persoanelor 
invalide. Și mai are în centru o preferință evidentă a scriitorului - eseist pentru istoria publică a cărții, atinsă, ca obiect de educație, plăcere estetică sau artă, de avalanșa noutăților tehnologice ale civilizației actuale. $\mathrm{O}$ mențiune specială îi este dedicată, în acest sens, gigantului cărții, Barnes\&Noble, care, după un marș triumfal ascendent, de până în anii 80, a decăzut ca urmare a urcușului năvalnic al companiei Amazon, care „și-a pus în minte să vândă cărți fără să deschidă nici măcar o singură librărie!"' 9] Și care și-a anunțat intenția de a cumpăra fosta librărie a Americii uzând de forța sa de capital, bazată (și) pe vânzarea de $e B o o k$ uri. Pe de altă parte, admirația eseistului se îndreaptă către Steve Jobs, ce asimila tehnologia cu una dintre formele de exprimare a umanității noastre și a gustului nostru pentru frumos.

În seria figurilor emblematice care intră în categoria Pop Art-ului actual se regăsesc Whitney Houston, J. R. Ewing sau... Thomas Jefferson, părinte al Constituției americane care „credea că negrii sunt lipsiți de emoțiile umane fundamentale". [10]

Dumitru Radu Popa construiește, astfel, o lume (perfect) postmodernă, pe orizontală, fără nici o ierarhie, deși selecția elementelor care alcătuiesc tabloul eclectic al Americii nu este inocentă. Juxtapunerea, funcționând ca pârghie pentru o contiguitate semantică și un efect metonimic implicit, (dez)organizează un conglomerat de elemente ce compun, paradoxal, un întreg (simbolic) funcțional - societatea americană.

Secvența intitulată Culturale, literare pornește de la extremismul funcționând sub flamura multiculturalismului și contestând dreptul la existență al religiilor - „greșeala fundamentală aici este că nu se ia în considerație ponderea cultural-istorică a religiei și a faptului că ea modelează, determină atâtea atitudini etnice, că - discreditată științific sau nu - face adesea parte din patrimonial intangibil al unor etnii, al unor națiuni".[11] - și, trecând prin proiectul de Bibliotecă universală al lui Eliade - primul președinte al Academiei Române, propune, printre altele, o incursiune prin istoriile existente ale literaturii române. Așa se face că Istoria literaturii române contemporane (1941 2000), a lui Alex. Ștefănescu, și Istoria critică a literaturii române. 5 secole de literatură, a lui Nicolae Manolescu, pierd competiția cu Istoria literaturii române de azi pe mâine, a lui Marian Popa, autorul acesteia din urmă fiind bănuit, în cadrul vânătoarei de vrăjitoare de după 1989, de a fi colaborat cu Securitatea.

Istoria cărților - de dincoace și de dincolo - continuă cu omagierea criticului literar Mircea Martin, la 70 de ani, model de comportament și de atitudine în raport cu actul de creație literară. Apoi, José Saramago și Memorialul de la Sighet, ca și distrugerea Cărții stau alături de o sentimentală 
elegie pentru scrisul de mână. Adusă și ea în discuție, cartea digitală, cu avantajele și dezavantajele ei, stă alături de Mona Lisa - problema restaurării culorilor rămâne încă nerezolvată, ca și de etapa în alb și negru a lui Picasso sau de mecenații americani care, precum Leonard A. Lauder - tycoon al industriei cosmetice, donează sute de tablouri de mare valoare muzeelor americane.

Aducerea trecutului (românesc) în prezent, având în centrul său simbolic cartea, prin numărul semnificativ de pagini dedicate ei, direct și indirect - prin omagierea creatorilor și a cititorilor ei de elită - continuă în ultima parte a eseurilor, intitulată De la lume adunate. Dintre ciudățeniile prezentate face parte uimitoarea cenzurare a lui Pinocchio, ocazionată de inițiativa Centrului italian de cultură din regiunea Toscana, de a oferi, gratuit, de Ziua copilului, un spectacol cu celebra păpușa de lemn, copiilor chinezi. Observațiile Beijingului au vizat, însă, faptul că băiețelul este cioplit din lemn - „fără norme morale”[12], că, „1̂mbrăcat așa cum este, pare mai degrabă nu o inocentă păpușă de lemn, ci un periculos agent al lui Dalai Lama, infiltrat în chiar centrul Beijingului"'[13], sau apariția zânei bune. Urmarea, de la sine înțeleasă, e că spectacolul a fost anulat.

Sub semnul hipertehnologizării actuale, și al permisivității duse la extrem, când vine vorba de inventivitate cu suport tehnologic, Infernul lui Dante poate deveni obiectul unui videogame. Înaintea lui, Alice în țara minunilor, romanul lui Lewis Carrol, și romanele lui Jules Verne au trecut, de asemenea, în virtual. Versiunea astfel obținută a Infernului propune un Dante inedit - „Drept care, în versiunea Electronic Arts, Dante se repede plin de furie în Infern. Pe pieptul cuirasat de armură are semnul Cruciaților, căci tocmai se întorsese din Cruciada împotriva păgânilor... E un erou macho, musculos, înarmat până în dinți și plin de furie pentru că, în timp ce el se bătea în Cruciadă, soția lui, frumoasa Beatrice, plictisită și sastisită să-1 tot aștepte, a cedat (...) la avansurile lui Lucifer care, după ce a sedus-o, a ucis-o ca să îi poată lua sufletul".[14] În noua poveste apar, fără nici o noimă culturală, și Elena din Troia, Clitemnestra ca ucigașa lui Agamemnon, murdară de sânge pe mâini, Caron și alții.

O altă curiozitate derivă din inițiativa unui om de afaceri sirian, Jaber Jasbbour, de a anula diferențele dintre engleza scrisă și engleza vorbită, printrun Saypu - Say as you pronounce universal alphabet - aici apărând varianta scrisă fonetic a englezei. Rezultatele posibile ale prelucrării alfabetului în uz - se elimină, de pildă, literele $C, Q$ și $X$, care i se par inovatorului inutile - sunt publicate, pentru ironică exemplificare, de un ziarist, în „Times": „tă bii or naat tă bii: that iz thă kwestshăn, echivalentul lui to be or not to be: that is the question".[15] 
Dincolo de ridicolul și de inaplicabilitatea acestei idei, ca și dincolo de toate celelalte ciudățenii ale acestei ultime secvențe a cărții, persistă imaginea reconfortantă a cărturarilor cu care volumul se deschide, ca și marea disponibilitate ironică a autorului, care face cu putință nu doar coabitarea tuturor celor prezentate aici (și a multor altora, nemenționate), ci și exorcizarea lor simbolică.

\section{Note}

[1] Dumitru Radu Popa, Din partea cealaltă. 2008 - 2013. Publicistică și eseuri, Ed. Scrisul românesc. Fundația - Editura, 2013.

[2] Idem, p. 13.

[3] idem, p. 17.

[4] idem, p. 28.

[5] Idem, p. 33.

[6] Idem, p. 40.

[7] Idem, p. 57.

[8] Idem, p. 63.

[9] Idem, p.74.

[10] Idem, p. 91.

[11] Idem, p. 109.

[12] Idem, p. 235.

[13] Ibidem.

[14] Idem, p. 249.

[15] Idem, p. 272.

\section{Bibliografie}

Bălan, Liliana, Dumitru Radu Popa sau dezinvoltura americană, disponibil la adresa ww.viataromaneasca.eu/arhiva/77_via-a-romaneasca-3-4-2012/79_diagonalele

exilului/1117_dumitru-radu-popa-sau-dezinvoltura-americana.html - consultat la 1.11.2018.

Cenac Oana, Discurs ideologic în "Ateneu" 1965, Actele conferinţei internaţionale Lexic comun / Lexic specializat. Democratizarea cunoașterii" sau migrația lexicului specializat spre lexicul comun, ediția a X-a, Universitatea "Dunărea de Jos” din Galați, Facultatea de Litere, Centrul de Cercetare Comunicare interculturală și literatură, 19 - 20 mai 2017, publicată în Analele Universității „Dunărea de Jos” din Galați, Fascicula XXIV Lexic comun / lexic specializat, revistă indexată in bazele de date internaționale EBSCO: https://www.ebscohost.com/titleLists/cms- 
coverage.pdf, MLA (Modern Language Association, New York, www.mla.org) MLA International Bibliography $\mathcal{E}$ Directory of Periodicals, CEEOL și Fabula. La recherche en littérature (www.fabula.org), anul X, nr. 2(18) /2017, Editura Casa Cărții de Ştiință, Cluj-Napoca, 2017, ISSN 1844-9476, p. 31-48.

Cenac Oana, General aspects of current political terminology, în Lexic politic - discurs politic, 2014, p.124-130, ISBN:978-606-17-0633-4, WOS: 000378358200007.

Ifrim, Nicoleta, History and Identity in Post-Totalitarian Memoir Writing in Romanian, CLCWeb: Comparative Literature and Culture (ISSN 1481-4374) http://docs.lib.purdue.edu/clcweb/, nr. 16.1 / March 2014, Purdue University Press, revistă indexată ISI Art and Humanities Citation Index http://docs.lib.purdue.edu/clcweb/vol16/iss1/11/, Accession Number WOS:000333326200011.

Ifrim, Nicoleta, Constructing and De-constructing Cultural Identity in the Contemporary European Paradigm - The Romanian Example and its Eurocentric Dilemmas, în ProcediaSocial and Behavioral Journal (ISSN: 1877-0428) (ISSN: 1877-0509),vol.63/2012,pp. 2934 DOI 10.1016/j.sbspro.2012.10.006, http://www.sciencedirect.com/science/journal/18770428/63/supp/C, WOS:000361477200005

Pîrvan-Jenaru, Dana, Un incomod agreabil, în „România liberă”, nr. 9/2008, disponibil la adresa http://www.romlit.ro/un incomod agreabil - consultat la 1.11.2018

Popa, Dumitru Radu, Din partea cealaltă. 2008 - 2013. Publicistică și eseuri, Ed. Scrisul românesc. Fundația - Editura, 2013. 